\title{
MOUTERE HILL COUNTRY DEVELOPMENT : A REVIEW
}

\author{
R. MARTIN \\ Transport (Nelson) Holdings Ltcl
}

\section{INTRODUCTION}

IN September 1956, Transport (Nelson) Holdings Ltd entered into an agreement to lease 910 ha at Redwoods Valley from the Crown for a 13-year term from lanuary 1, 1957. The Redwoods Valley area is $29 \mathrm{~km}$ from Nelson, with saleyards, fertilizer works and freezing works within a $\mathbf{1 6} \mathrm{km}$ radius. The area leased was in an unimproved state with a cover of gorse, fern, heather, and pines. A condition of the lease was that the lessee develop 35 ha/yr and it was expected that 300 ha could be developed.

In November 1963, Transport (Nelson) Holdings Ltd entered into an agreement with the Crown to purchase the freehold of the property by way of a deferred payment licence. To round off boundaries, two other properties of 40 and 15 ha were purchased in January 1957, and a further 75 ha in 1961, all in a reverted state.

\section{GENERAL DESCRIPTION}

The land has a sunny aspect, with the leading ridge, running from east to west, rising from 45 to $250 \mathrm{~m}$ above sea level. The east and lower slopes are of easy contour; the western end has steeper slopes and there are small areas of flat and some shady hill sides.

The region has a sunny climate with moderate temperatures. An average rainfall of $880 \mathrm{~mm}$ is concentrated mainly in winter and spring, 4 years out of 5. January to March is very dry with very little pasture growth.

The soil is Mapua sandy loam of the Moutere gravel series, the main features of these soils being the low natural fertility and strong acidity. It is responsive to phosphate, lime, potassium, molybdenum, selenium, cobalt, copper, sulphur and boron.

Internal access roads have been formed and culverted. Tracks leading to all areas of the farm are of 4-wheel drive and dryweather car standard. 
An airstrip with bulk fertilizer bin is in the centre of the property, the strip being fenced into a 6 ha paddock.

A water reticulation scheme was completed using water from a stream on the southern boundary and a spring in the northern slopes. Diesel-driven pumps were used to pump the water to two 22400 litre concrete tanks on the highest ridge and polythene pipe was laid to water troughs in each paddock. This scheme was essential and successful, but as the quality of the water deteriorated it was decided in 1973 to purchase an adjoining 24 ha which made available an underground water supply from the Waimea Plains. Some ncighbouring farms were also given access to this new supply. The water is pumped through some $13 \mathrm{~km}$ of piping. The daily summer requirement is about 100000 litres.

Four dwellings have been built and an older residence renovated. Other buildings comprise a 4-stand woolshed, holding 700 ewes in night pens, shearers' quarters, men's quarters, seed shed, 7 hay sheds, providing storage for 30000 bales, three sets of sheep yards, and three sets of cattle yards with full facilities in two sets.

Present staff comprises three married men, two single men, and the manager. Assistance with hay comes from within the group. Shearing is done with four contract shearers and two shed hands plus farm stafi.

\section{DEVELOPMENT}

The area decided on for development would be double giantdisced in autumn and fallowed for six months. After fallowing, the area would be .burnt over with the able and welcome assistance of the local Forest Service and H. Baigent \& Sons. The area would then be disced again and worked down to a seedbed for January-February sowing.

Because we had an excellent team of tractors and drivers under the control of the late V. Krammer, about 720 ha were cleared and sown within the first four years.

\section{MACHINERY USED}

It would be only fair to mention Tony Coleman, our chief tractor driver, who was with us for most of the time for this type of work. I have not seen a better tractor driver: if conditions were right nothing was impossible. We used D6B type tractors, $75 \mathrm{~cm}$ six-a-side giant discs, cultivators and heavy harrows made out of used track chains, $60 \mathrm{~cm}$ tandem discs, cam- 
bridge rollers and spinner-type topdresser, plus light chain harrows for covering the seed. The seed was mixed with the lime and fertilizer and spun on through the topdresser.

Changes made if doing the job again would include more attention to checking regrowth of gorse, and additional lime, but otherwise nothing major.

\section{SEED}

Only certified seed was used at the following rates per hectare:

$17 \mathrm{~kg}$ Ruanui perennial ryegrass

$6 \mathrm{~kg}$ Manawa short-rotation ryegrass

$3 \mathrm{~kg}$ Huia white clover

$6 \mathrm{~kg}$ Apanui cocksfoot

Mt Barker subterranean clover has been sown and turnips added if required.

Good crops of swedes and lucerne have been grown, but lucerne and gorse seem to be very friendly and grow well together. However, 2,4,5-T kills both of them. We have used $9 \mathrm{~kg}$ of oats when the seedbed became too fine and dry and rain was likely to cause rilling. There has been no major erosion. There are areas, however, which would benefit from a tree-planting programme.

\section{FERTILIZER AND LIME}

At sowing, 1 tonne of lime and $375 \mathrm{~kg}$ of molybdic superphosphate are applied, then $375 \mathrm{~kg} / \mathrm{ha}$ applied in spring with an annual topdressing of $375 \mathrm{~kg} / \mathrm{ha}$ of $20 \%$ potassic superphosphate. Boron is added on some paddocks to stimulate clover growth and cobalt has been used in 1976.

\section{FENCING FOR DEVELOPMENT}

Each block was ring-fenced into approximately 90 ha blocks, temporary fences used to control feed, and finally fenced into 12 to 20 ha areas which have been found very good for stock management. To start with, the stocking rate was 10 units/ha, and sheep were purchased from as far away as Feilding and Invercargill with no problems. Romneys are the main breed used. Corriedales were tried, but, owing to foot rot problems, were discontinued.

In the programme of improvement, the company has had the benefit of advice from Cawthron Institute, Ministry of Agricul- 
ture and Fisheries, Lands and Survey Department, and Nelson Catchment Board. Costs of development at today's prices would be about $\$ 500 /$ ha plus livestock, buildings and water.

\section{CURRENT SITUATION}

The total holding now comprises 1100 ha of which 120 ha are in rough, 40 ha are in lucerne, 50 ha are in crops, and 890 ha are in permanent pasture.

In 1972, the company asked me to consider Simmental cattle in the country with a view to setting up a Simmental stud. After extensive travel in the North and South Islands, I felt that the breed had something to offer as it appeared to be doing well under a wide range of conditions. After that trip it was decided to start a breeding-up programme to breed approximately 400 stud cows. To assist in achieving this, we set up a calf-rearing programme supplying semen to dairy farmers and taking the Simmental half-bred female calves at 6 days to rear on the farm. This programme handles 500 calves without too many problems.

Artificial breeding techniques are used, together with three resident purebred sires. To make maximum use of sires, and spread the work load, calving is done in both autumn and spring.

The present carrying capacity in stock units is: Winter cattle, 8150, sheep, 4400, a total of 12 550. Summer - cattle, 8150 , sheep, 5200, a total of 13350 .

Calving percentage is 95 and lambing percentage varies from 85 to 100 depending on conditions when the rams go out. With the change to cattle better results might be expected.

Lamb weights vary from 13 to $15 \mathrm{~kg}$, all lambs being fattened. It is intended to run 4500 ewes plus 400 stud cows with supporting stock.

We have 80 paddocks plus 7 holding paddocks, and rotational grazing plus short-term set-stocking is practised.

Originally hay was purchased, but the weeds that came with bought-in hay made this a very costly practice. With the flat land purchased, it is now possible to meet all winter and summer requirements of supplementary feed. We make our own meal for the calves, and grow our own grain for meal requirements.

Gorse and pine trees are both weeds where not wanted and pine trees leave the soil in very poor condition. It takes a long time to establish a good pasture after pines, but it can be done. Pasture is easily established after gorse, but seedlings require attention for many years or reversion to gorse will soon take place, and gorse responds well to topdressing. Spot spraying 
has been carried out and at times we seemed to be losing, but now 1 can say that the battle is being won.

Walnut and hazelnut trees are being planted for shade and shelter in the future.

I have enjoyed the challenge that this marginal land has given and should like to congratulate J. Newman, Chairman of Directors of Transport (Nelson) Holdings Ltd, whose enthusiasm has been a great encouragement, also the Board of Directors for their foresight in making possible this achievement. It has resulted in the creation of a fine asset for the company and the district. It has also made possible water for neighbouring farms, an outlet for dairy beef calves, and stock for the local works.

The project was undertaken originally to demonstrate that this type of country was suitable for grassland farming. Financially, over a long term it must be a success.

\section{FUTURE IN FARMING MOLJTERE CQUNTRY}

As the plains are turning into small holdings suitable for market gardening, Nelson must look more and more to the hills for its livestock farming. At present forestry would be gaining most undeveloped land, but an up-turn in farming income would change this. It is a long-term project with no short cuts that we know of and needs long-term finance to bring it into full production.

Subdivision would not be desirable for a few years yet, I consider, as it would result in the loss of hay paddocks for some blocks.

The general opinion of outsiders over the years seemed to be doubt that the development of this country would be a success. In fact, it was a considerable task, but this is now almost completed and pasture production is better than expected for this type of country. 1 am very proud to have played a part in it.

\section{ACKNOWLEDGEMENTS}

Help and guidance over the years have been given by a number of people, and acknowledgement is made to Charles Cran who was responsible for my taking on the task in the first instance, to. Dick Inch of the Department of Agriculture, the late Cliff Jackman and Jeff Jordan of Kempthorne, Prosser \& Co., and to Eric Chittenden from the Cawthron Institute. Many others have also given freely of their wealth of knowledge and advice and this has been very much appreciated. 